\title{
LUCIAN BLAGA KÖZPONTI EGYETEMI KÖNYVTÁR
}

„Lucian Blaga” Központi Egyetemi Könyvtár

Cím: Kolozsvár, Clinicilor utca 2.

Honlap: https://www.bcucluj.ro/hun

E-mail: secretariat@bcucluj.ro

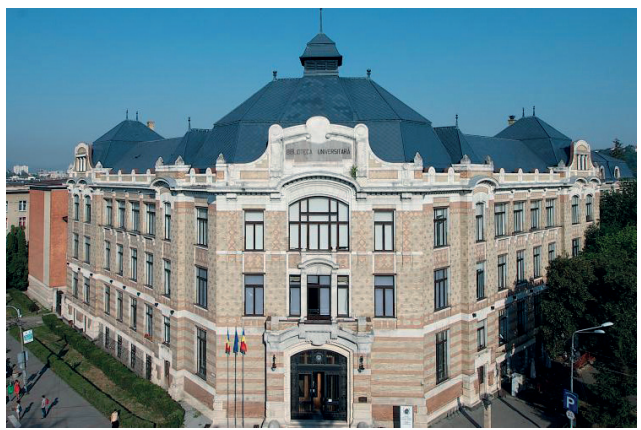

A kolozsvári Lucian Blaga Központi Egyetemi Könyvtárat 1872-ben alapították, a Ferenc József Tudományegyetemmel egyidőben. Első igazgatója Szabó Károly volt, a jeles történész és bibliográfus, aki sokrétű tevékenységével megalapozta a könyvtár későbbi fejlődését. A gyűjtemény alapját a volt kolozsvári Jogakadémia, illetve az Erdélyi Múzeum-Egyesület könyvtárai képezték. Már a kezdet kezdetén arra törekedett a könyvtár, hogy minél hatékonyabban, az egyre növekvő igényeknek megfelelően gyarapítsa gyűjteményeit, újabb és újabb módszereket alkalmazva a kiadványok feldolgozásában. Így a könyvtárnak kis, de biztos lépésekkel sikerült beépülnie az eszmék európai áramlatába, amit nagymértékben tanúsít a jelzett időszakban beszerzett gyüjtemények jellege is.

A 20. század első éveiben, Erdélyi Pál irodalomtörténész igazgatósága alatt, újabb jelentős fejlődés volt tapasztalható könyvtárunk életében, ugyanis az 1906-1907-es években valósult meg az új, szecesszíós stílusú könyvtári épület, amely a továbbiakban több magyarországi és más európai könyvtár számára is példáként szolgált. Az 1908-as beköltözést követően, az intézmény korszerű felszerelésével együtt, a korabeli Magyarország legmodernebb könyvtárává vált. Utólag újabb raktárépület, valamint olvasótermek egészítették ki a Giergl Kálmán és Korb Flóris által tervezett palotát, harmonikusan illeszkedve az épület eredeti stílusába.

Az évek folyamán olyan jelentős személyiségek dolgoztak könyvtárunkban, mint az irodalomtörténész Ferenczi Zoltán - aki Kolozsvárról való távozása után a Magyar Tudományos Akadémia Könyvtárának lett az igazgatója -, a művelődéstörténész Kelemen Lajos, a hírlapíró Gyalui Farkas, a genealógus Köblös Zoltán, a bibliográfus Valentiny Antal, valamint Veress Endre, a magyar-román kapcsolatok kiváló kutatója.

Csaknem négymillió kötetével intézményünk jelenleg Erdély legnagyobb könyvtára. Különleges gyüjteményei 5972 kéziratot, 86 ősnyomtatványt, 5123 régi magyar könyvet, 1213 


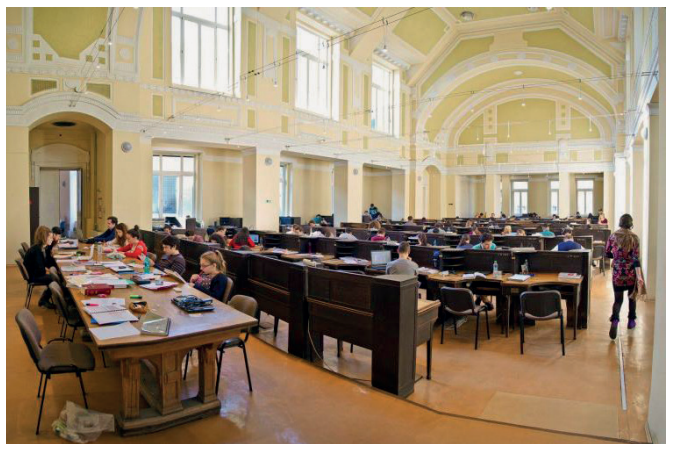

régi román könyvet, valamint több mint 50000 képeslapot számlálnak. A könyvtár gyüjteményeit 2019-ben több mint 17000 olvasó használta. Az intézményben jelentős tudományos tevékenység is zajlik, mely bibliográfiákban, forráskiadványokban, tanulmánykötetekben ölt testet. Az intézmény 1996 óta kiadója a Philobiblon - Transylvanian Journal of Multidisciplinary Research in Humanities címü referált lapnak. E sokrétű tevékenységhez nyújt kiemelkedő segítséget az Elektronikus Információszolgáltatás Nemzeti Program keretében biztosított adatbázis-hozzáférés.

Győrfi Dénes

Nagyenyeden a Bethlen Gábor Kollégiumban érettségizett, majd 2004-ben a kolozsvári Babeș-Bolyai Tudományegyetemen történelem-könyvtár szakon diplomázott. Az egyetemen 2012-ben szerzett doktori fokozatot. 2004 óta a kolozsvári Lucian Blaga Központi Egyetemi Könyvtárban, az Állománygyarapítási Osztályon dolgozik. 